\title{
Evaluation of tensile strength and fracture behavior of friction welded dissimilar steels under different rotational speeds and axial pressures
}

\author{
AMIT HANDA $^{1, *}$ and VIKAS CHAWLA ${ }^{2}$ \\ ${ }^{1}$ RIMT-Institute of Engineering and Technology, Mandi Gobindgarh, \\ Punjab, India \\ ${ }^{2}$ Ferozepur College of Engineering and Technology, Ferozeshah, Punjab, India \\ e-mail: handaamit_2002@yahoo.com
}

MS received 21 December 2013; revised 22 November 2014; accepted 14 February 2015

\begin{abstract}
In the present study an attempt was made to join austenitic stainless steel (AISI 304) with low alloy steel (AISI 1021) at five different rotational speeds ranging from 800 to $1600 \mathrm{rpm}$ and at as many different axial pressures ranging from $75 \mathrm{MPa}$ to $135 \mathrm{MPa}$ and then determining the strength of the joint by means of tensile strength. Furthermore scanning electron microscope analysis was performed to evaluate the pattern of failure at the fractured locations, also the micro hardness was checked at the weld interface and at distances on either side of the weld joint to evaluate the effect of heat. The highest tensile strength achieved by the welded specimens was $1.8 \%$ higher than the AISI 1021 steel and the lowest tensile strength obtained was $20 \%$ lower than the parent AISI 1021.
\end{abstract}

Keywords. Friction welding; tensile strength; SEM; microhardness.

\section{Introduction}

Joining of the metals is one of the most essential needs of the industry (Handa \& Chawla 2013a). The joining has increasingly been used in the materials technology because of the materials having different mechanical properties needs to be efficiently and effectively joined to increase their performance (Uzkut et al 2011). Welding is one of the fast growing principal technologies used for joining materials which is almost used by all the fabricating industries. There are many situations arises in the industries where dissimilar metals need to be welded. The growing availability of new materials and higher requirement being placed on materials creates a greater need for joints of dissimilar metals (Satyanarayana et al 2005). Dissimilar joints between austenitic stainless steel and low alloy steel are extensively used in many high temperature applications in the energy conversion system (Chander et al 2012). There is a comprehensive need for dissimilar

${ }^{*}$ For correspondence 
metal joints in power plant components, due to the severe gradients in mechanical and thermal loading. In central power stations, the parts of the boiler that subjected to lower temperatures are made of low alloy steel for economic reasons. The other parts, operating at higher temperatures, are constructed with austenitic stainless steel. Therefore, transition welds are needed between these two materials. The joining of dissimilar materials is generally more challenging than that of the similar materials due to difference in thermal, metallurgical and physical properties of the parent materials. Thus it is difficult to obtain good quality weld joints using conventional welding techniques and some defects and intermetallic phases can occur during the process because of significant difference in mechanical and chemical properties (Kurt et al 2011). The specific problems associated with welding of austenitic stainless steel are formation of delta ferrite, sigma phase, stress corrosion cracking, and sensitization at the interface (Chander et al 2012). Friction welding is one such solid state welding process widely employed in such situations (Meshram et al 2008; Sathiya et al 2007). Friction welding is a solid state joining process in which the heat for joining is generated by the relative motion between the two interfaces being welded. This method relies on the direct conversion of mechanical energy into thermal energy to form the bond (ASM Handbook 1993).

\section{Experimental details}

Austenitic stainless steel AISI 304 and low alloy steel AISI 1021 specimens having diameter of $20 \mathrm{~mm}$ and $100 \mathrm{~mm}$ length were joined together by means of friction welding. The chemical composition of austenitic stainless steel and low alloy steel is presented in table 1. A continuous drive (Reddy \& Rao 2009) lathe machine was used for the experimentation. The modified lathe machine was used for the friction welding of the specimens; axial pressures were monitored from the load cell fitted on the machine (Handa \& Chawla 2013a). Test samples were fabricated on the friction welding set-up for the experimentation, before welding, the contacting surfaces of the specimens were faced on the lathe machine and then cleaned using Acetone (Sathiya et al 2005). The required rotational speeds of $800,1000,1250,1430$ and $1600 \mathrm{rpm}$ were set by the levers attached on this machine. Within a fraction of seconds, the predetermined constant speed was achieved; subsequently the axial alignment of the specimens was checked and then the axial pressure was applied. When the required forging temperature has been achieved, the rotation of the specimen was ceased by applying brakes. The welds were prepared at different axial pressures in the steps of $15 \mathrm{MPa}$ starting from $75 \mathrm{MPa}$ to $135 \mathrm{MPa}$ to form different welds for the study. The weldments so produced were allowed to cool down for 4-5 min. In this way, necessary number of weldments were prepared for the evaluation of their strength. Figure 1 shows the friction welded specimens at different rotational speeds and axial pressures.

All the specimens for the current study were prepared at five different rotational speeds and five different axial pressures. Friction welding parameters for the current study were obtained from the literature and the preliminary work (Sahin 2009; Vinoth \& Balasubramanian 2014; Satyanarayana et al 2005; Sahin et al 2007; Celik \& Ersozlu 2009). In this experimental study, different combinations of specimens were obtained by varying the rotational speeds and axial

Table 1. Chemical composition of the parent materials.

\begin{tabular}{lcccccccc}
\hline Metal & $\mathrm{Cr}$ & $\mathrm{Ni}$ & $\mathrm{C}$ & $\mathrm{Mn}$ & $\mathrm{Si}$ & $\mathrm{P}$ & $\mathrm{S}$ & $\mathrm{Fe}$ \\
\hline AISI 304 & $17-20$ & $9-13$ & 0.08 & 2 & 0.75 & - & - & Remaining \\
AISI 1021 & - & - & $0.15-0.25$ & $0.6-0.9$ & - & - & - & Remaining \\
\hline
\end{tabular}




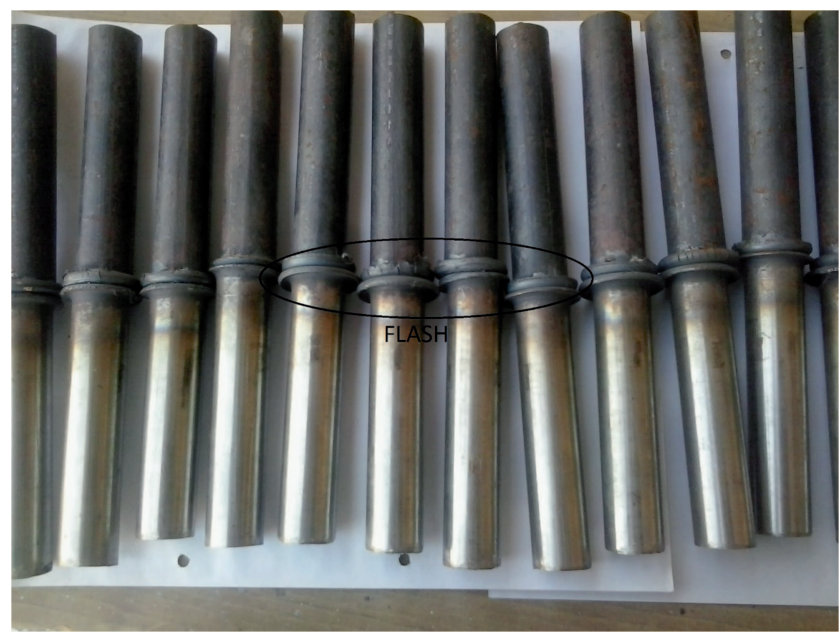

Figure 1. Friction welded specimens at different axial pressures and rotational speeds.

Table 2. Actual mechanical properties of the parent materials.

\begin{tabular}{lcc}
\hline Metal & Tensile strength & Average microhardness \\
\hline AISI 1021 & $473 \mathrm{MPa}$ & $188 \mathrm{Hv}$ \\
AISI 304 & $529 \mathrm{MPa}$ & $202 \mathrm{Hv}$ \\
\hline
\end{tabular}

pressures while the temperature at the weld interface was kept constant; the temperature was monitored with the help of infrared thermometer and the axial pressure was set by the load cell attachment fitted on the lathe machine. Furthermore, the actual mechanical properties of the parent materials, after experimentation is reported in table 2.

\subsection{Work methodology}

Friction welded parts were subjected to tensile strength tests, fractography behavior and microhardness to determine their optimum bond interface strength for the anticipated service applications. They were necessary to carry out so as to ensure the quality, reliability and strength of the welded joints.

2.1a Tensile test: Tensile test was performed on the Universal Testing Machine having the capacity of 60 tons. The standard specimens were prepared using ASTM standards. The gauge lengths of the specimens were maintained according to the ASTM A370-12 maintaining the weld interface at the center of the gauge length. The sample was then fitted firmly between the jaws of the machine and load was applied. This test was carried out on the friction welded samples of AISI 304 with AISI 1021 materials to measure their strength in tension. In this test the specimen was subjected to axial loading till its failure.

2.1b Fractography test: Fractograpy analysis is used to determine the type of failure in engineering materials by studying the characteristics of fractured surfaces. Different types of crack growth produce characteristic features on the fractured surfaces, which can be used to identify 
the mode of failure. So to determine the mode of failure in tensile test, Scanning electron microscope (SEM) analysis was performed. SEM of make JEOL model JSM-6610LV was used. The SEM analysis was carried out to show the fracture behavior of tensile test which justifies the visual inspection results of brittle and ductile failures. The magnified images were captured at the fractured locations taken at $1500 \times$ magnification.

2.1c Microhardness: For microhardness testing, Vickers hardness testing machine was used. In this test, a square based pyramid type diamond indenter was used and the hardness variation on the weld interface was monitored. Moreover, the hardness across the weld interface on both the parent materials was also obtained. A 500 gf gradual load was applied for a dwell time of $10 \mathrm{~s}$. The indentations were made at the weld interfaces, and on the sides of both the parent materials, along the axis of the shaft at the regular intervals of $1 \mathrm{~mm}$ to as to determine the effect of frictional heat on the hardness variations.

\section{Description and discussion of achieved results}

The friction welded specimens of 25 different welding combinations were prepared by varying five different axial pressures and as many rotational speeds; it was observed that the flash has been generated at the welding interface during friction welding process and the amount of flash increased with the rise in axial pressure; the flash was also observed to be increased with the increase in rotational speeds as well. The formation of flash has been shown in figure 1. It has also been observed from the figure that for every friction welded sample, the formation of flash is higher towards the low alloy steel than that of the austenitic stainless steel for all the cases. This might be attributed to the presence of $\mathrm{Cr}$ in austenitic stainless steel; as AISI 304 having lower thermal conductivity as compared to low alloy steel, for this reason the formation of flash is higher on the AISI 1021 side than the AISI 304 side, also austenitic stainless steel having greater hardness at higher temperatures as compared to low alloy steels. For this reason austenitic stainless steel does not undergo extensive deformation while the low alloy steel undergoes extensive deformation. This phenomenon may be attributed to the low strength of AISI 1021 steel (Handa \& Chawla 2013b).

\subsection{Tensile testing}

Universal testing machine of HEICO make having the maximum capacity of $600 \mathrm{KN}$ load with load accuracy of $\pm 1 \%$ and displacement accuracy of $\pm 1 \%$ was used. The specimens were loaded gradually till the specimen fractures. The graphs were plotted on the basis of the results obtained from the test. It has been observed experimentally that most of the specimens failed at the joint interface. However, some of the specimens, cup and cone shape was observed at the fractured locations and showed the ductile failure behavior, their fracture point was not at the weld interface but it was found to be towards the weaker parent material. It has been observed during the experimentation that as we go on increasing the axial pressure the tensile strength goes on increasing, the tensile strength also goes on increasing with the increase in rotational speed. Also it has been noted that the tensile strength firstly increases, reaches to the maximum value and then starts declining with the further increase in parameters. Table 3 shows the peak values of stress and strain achieved at every combination of axial pressure and rotational speed. It has been observed experimentally that as we go on increasing the axial pressure keeping the rotational speed constant, the value of stress also shows increase in trend. The value of stress also found to 
Table 3. Results of tensile test.

\begin{tabular}{lccccccccccc}
\hline & & $\begin{array}{c}\text { Peak } \\
\text { stress } \\
(\mathrm{MPa})\end{array}$ & $\begin{array}{c}\text { Peak } \\
\text { strain }\end{array}$ & $\begin{array}{c}\text { Peak } \\
\text { stress } \\
(\mathrm{MPa})\end{array}$ & $\begin{array}{c}\text { Peak } \\
\text { strain }\end{array}$ & $\begin{array}{c}\text { Peak } \\
\text { stress } \\
(\mathrm{MPa})\end{array}$ & $\begin{array}{c}\text { Peak } \\
\text { strain }\end{array}$ & $\begin{array}{c}\text { Peak } \\
\text { stress } \\
(\mathrm{MPa})\end{array}$ & $\begin{array}{c}\text { Peak } \\
\text { strain }\end{array}$ & $\begin{array}{c}\text { Peak } \\
\text { stress } \\
\text { (MPa) }\end{array}$ & $\begin{array}{c}\text { Peak } \\
\text { strain }\end{array}$ \\
Sample & $\begin{array}{c}\text { Axial } \\
\text { no. }\end{array}$ & $\begin{array}{c}800 \\
\text { (MPa) }\end{array}$ & $\begin{array}{c}800 \\
\text { rpm }\end{array}$ & $\begin{array}{c}1000 \\
\text { rpm }\end{array}$ & $\begin{array}{c}1000 \\
\text { rpm }\end{array}$ & $\begin{array}{c}1250 \\
\text { rpm }\end{array}$ & $\begin{array}{c}1250 \\
\text { rpm }\end{array}$ & $\begin{array}{c}1430 \\
\text { rpm }\end{array}$ & $\begin{array}{c}1430 \\
\text { rpm }\end{array}$ & $\begin{array}{c}\text { rpm } \\
\text { rpm }\end{array}$ & $\begin{array}{c}1600 \\
\text { rpm }\end{array}$ \\
\hline S1 & 75 & 382 & 0.07 & 379 & 0.16 & 389 & 0.16 & 405 & 0.23 & 397 & 0.15 \\
S2 & 90 & 391 & 0.12 & 406 & 0.17 & 419 & 0.17 & 429 & 0.26 & 433 & 0.16 \\
S3 & 105 & 390 & 0.16 & 429 & 0.17 & 443 & 0.24 & 464 & 0.33 & 442 & 0.17 \\
S4 & 120 & 392 & 0.17 & 424 & 0.17 & 457 & 0.33 & 481 & 0.44 & 432 & 0.10 \\
S5 & 135 & 408 & 0.11 & 426 & 0.17 & 467 & 0.37 & 467 & 0.37 & 400 & 0.01 \\
\hline
\end{tabular}

be increasing with increasing the rotational speed and keeping the axial pressure constant. This phenomenon was observed to be true if the rotational speed was increased up to $1430 \mathrm{rpm}$, with the further rise in rotational speed the trend starts moving towards the opposite path even though the difference in the stress values is marginal. But on the other hand if we consider the comparative value of strain, the difference was found to be significant. Figures 2-6 show the variation of stress vs strain at $800,1000,1250,1430$ and 1600 rotational speeds by varying the axial pressures from $75 \mathrm{MPa}$ to $135 \mathrm{MPa}$ in the steps of $15 \mathrm{MPa}$ at each rotational speeds. Figure 2 depicts that with the increase in axial pressure, the stress increases, this might be attributed that with the increase in axial pressure and rotational speed more mass is thought to be transferred at the interfaces (Handa \& Chawla 2013b). The similar trends have been reported by Arivazhagan et al (2011). The value of strain also goes on increasing with the rise in axial pressure but if the pressure increases beyond $120 \mathrm{MPa}$, the value of strain decreases little bit even though the maximum stress in this figure was found at $135 \mathrm{MPa}$. Similar results were found to happen in figure 3, all the specimens of figures 2 and 3 failed at the joint interface. In figure 4, the specimens were prepared at $1250 \mathrm{rpm}$, tensile tested and it was observed that the specimens welded at $75 \mathrm{MPa}, 90 \mathrm{MPa}$ and $105 \mathrm{MPa}$ were failed at the weld interface but they show necking behavior before getting failed at the interfaces. The welded specimens at $120 \mathrm{MPa}$ and $135 \mathrm{MPa}$ were the first specimens not to be fractured at the weld interface but away from it and failure was towards weaker material (AISI 1021). The maximum strain obtained here was 0.37 and maximum stress was observed to be $467 \mathrm{MPa}$. The similar results have been observed in figure 5, the first two

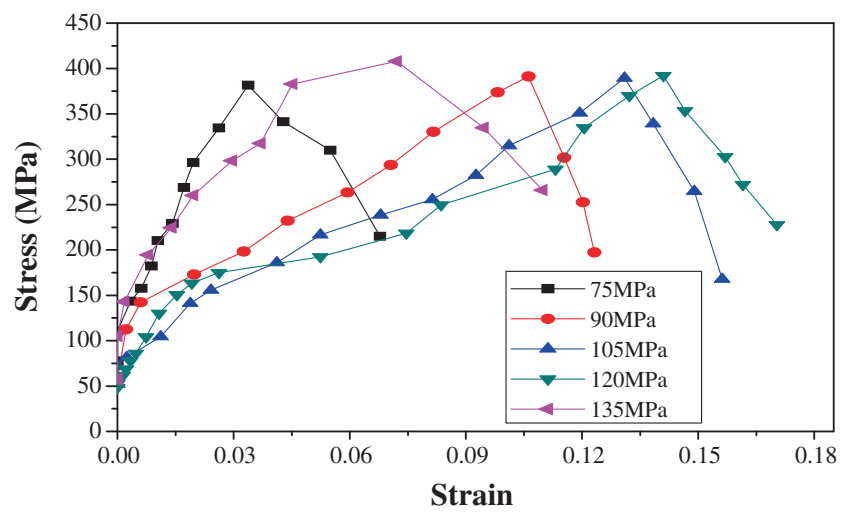

Figure 2. The variation between Stress vs Strain at $800 \mathrm{rpm}$. 


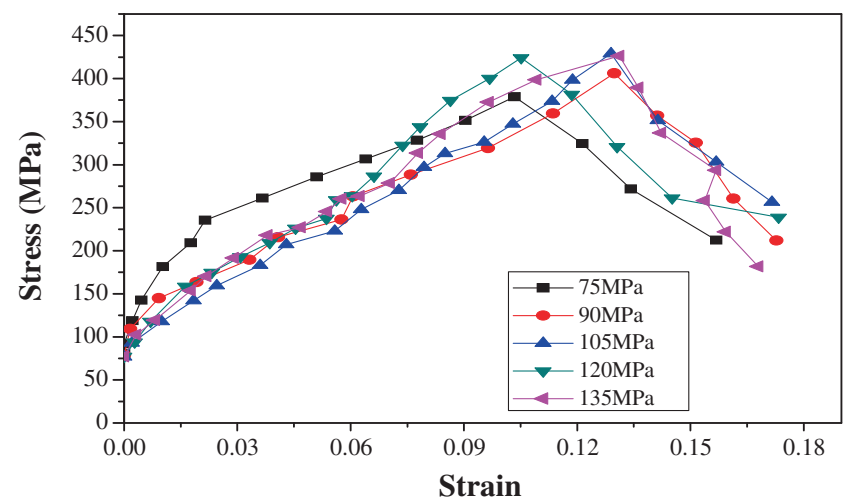

Figure 3. The variation between Stress vs Strain at $1000 \mathrm{rpm}$.

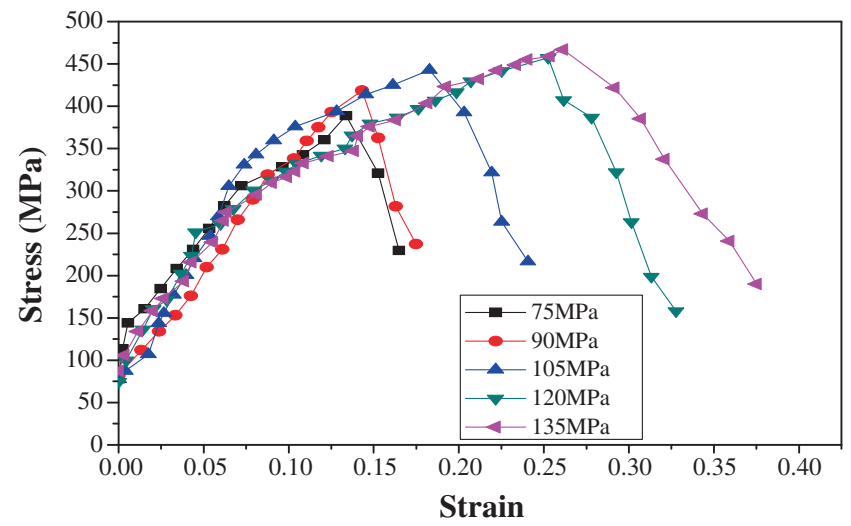

Figure 4. The variation between Stress vs Strain $1250 \mathrm{rpm}$.

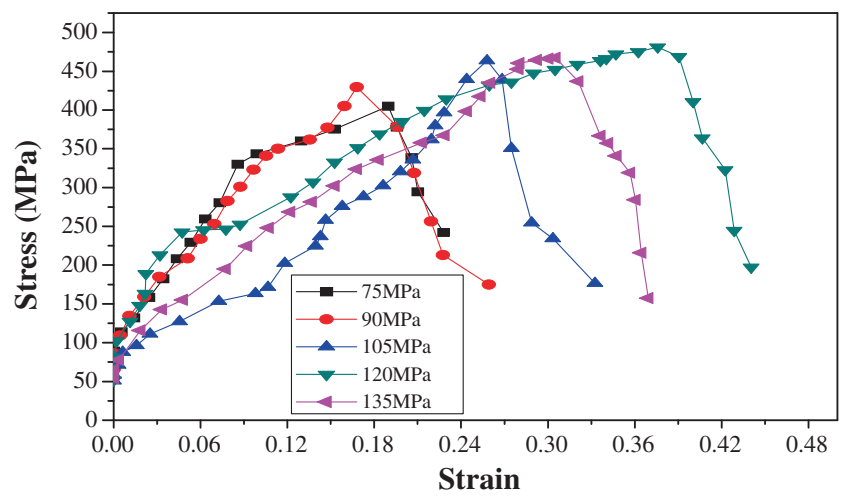

Figure 5. Shows the variation between Stress vs Strain $1430 \mathrm{rpm}$.

specimens were failed at the joint interface with necking and the remaining three specimens were failed at the weaker material and not at the joint. The maximum value of stress as well as strain which was $481 \mathrm{MPa}$ and 0.44 respectively was obtained at $1430 \mathrm{rpm}$ and at $120 \mathrm{MPa}$ axial 


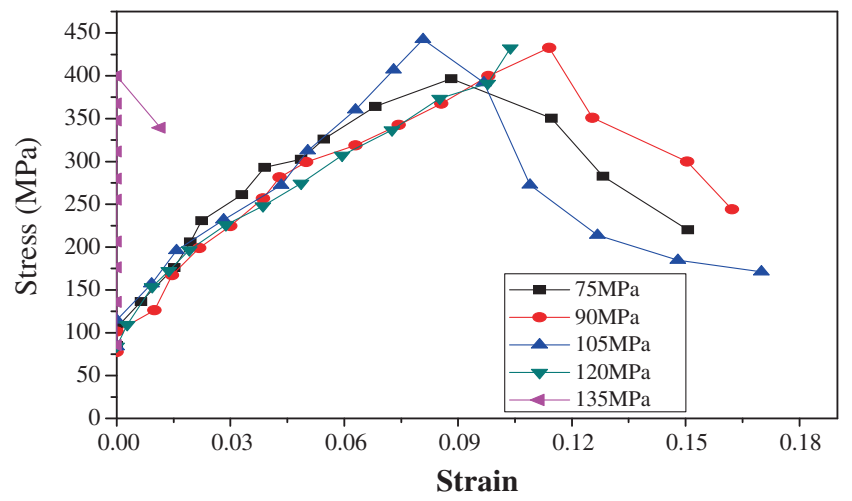

Figure 6. Shows the variation between Stress vs Strain $1600 \mathrm{rpm}$.

pressure for all the specimens. It has also been observed that maximum time was taken by the machine $(37 \mathrm{~s}$ ) to fracture the specimen welded at this parameter combination. Figure 5 depicts the stress vs strain behavior of the specimens welded at $1600 \mathrm{rpm}$. All the specimens were failed at the joint without showing any significant necking. Also the stress increases with the increase in axial pressure up to $105 \mathrm{MPa}$ pressure, a start declining with the further increases in pressure but the difference is marginal although there was drastic decline in the strain values, they marginally increase up to $105 \mathrm{MPa}$, reaches almost up to 0.01 at $135 \mathrm{MPa}$ axial pressure. Minimum time has been taken by the machine to fracture the specimen welded at $1600 \mathrm{rpm}$ and at $135 \mathrm{MPa}$ axial pressure which was $11 \mathrm{~s}$. This was due to that, under high friction force and high rotational speeds, peak temperatures are attained in very short time, compared to low friction force conditions (Chander et al 2012). Under these conditions higher heat input rates and low weld times results in the rapid cooling of the material. This results in the formation of martensite on low alloy steel side. This martensite being hard and brittle shows less ductility and strength. The tensile test results are in good agreement with literature (Handa \& Chawla 2013a).

Weld strength of tensile tested friction welded specimens (in percentage) compared with unwelded AISI 1021 parent metal has been reported in table 4. The maximum achieved tensile strength was $1.8 \%$ higher than the AISI 1021 parent metal and was found to available at 1430 $\mathrm{rpm}$ and at $120 \mathrm{MPa}$ axial pressure, while the lowest tensile was found to be at $1000 \mathrm{rpm}$ and at $75 \mathrm{MPa}$ and was $80 \%$ of the AISI 1021 parent metal. Similar results have been reported by Celik $\&$ Ersozlu (2009). Figure 7 indicates the stress strain curves of the un-welded parent metals

Table 4. Weld strength of tensile tested friction welded specimens (in percentage) compared with unwelded AISI 1021 parent metal.

\begin{tabular}{lcccccc}
\hline & Percentage & $\begin{array}{c}\text { Percentage } \\
\text { tensile } \\
\text { tensile } \\
\text { strength at } \\
\text { strength at } \\
\text { Sample no. }\end{array}$ & $\begin{array}{c}\text { Percentage } \\
\text { tensile } \\
\text { strength at } \\
1250 \mathrm{rpm}\end{array}$ & $\begin{array}{c}\text { Percentage } \\
\text { tensile } \\
\text { strength at } \\
1430 \mathrm{rpm}\end{array}$ & $\begin{array}{c}\text { Percentage } \\
\text { tensile } \\
\text { strength at } \\
1600 \mathrm{rpm}\end{array}$ \\
\hline S1 & 75 & 80.7 & 80.1 & 82.2 & 85.6 & 83.9 \\
S2 & 90 & 82.6 & 85.8 & 88.6 & 90.9 & 91.5 \\
S3 & 105 & 82.4 & 90.7 & 93.6 & 98.1 & 93.4 \\
S4 & 120 & 82.8 & 89.6 & 96.6 & 101.8 & 91.3 \\
S5 & 135 & 86.2 & 90 & 98.7 & 98.7 & 84.5 \\
\hline
\end{tabular}




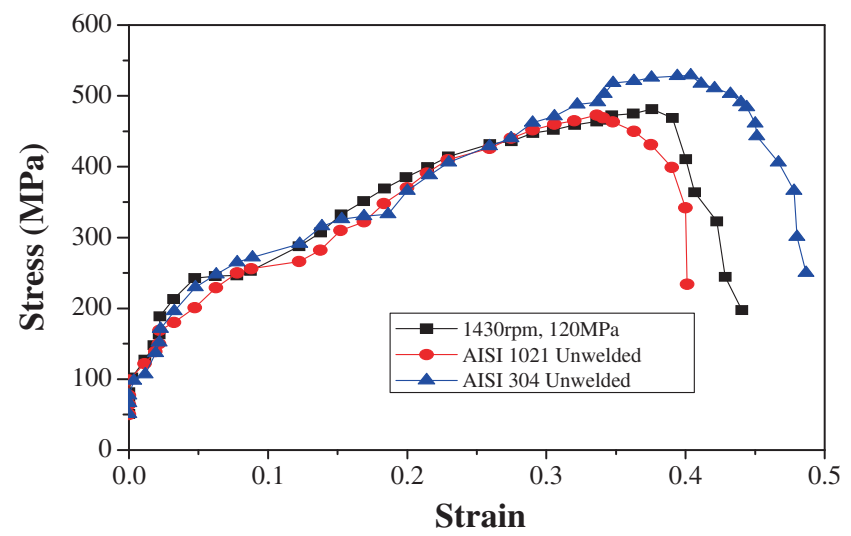

Figure 7. Depicts the variation between Stress vs Strain of the Un-welded Parent metal in comparison with the friction welded specimen showing maximum tensile strength.

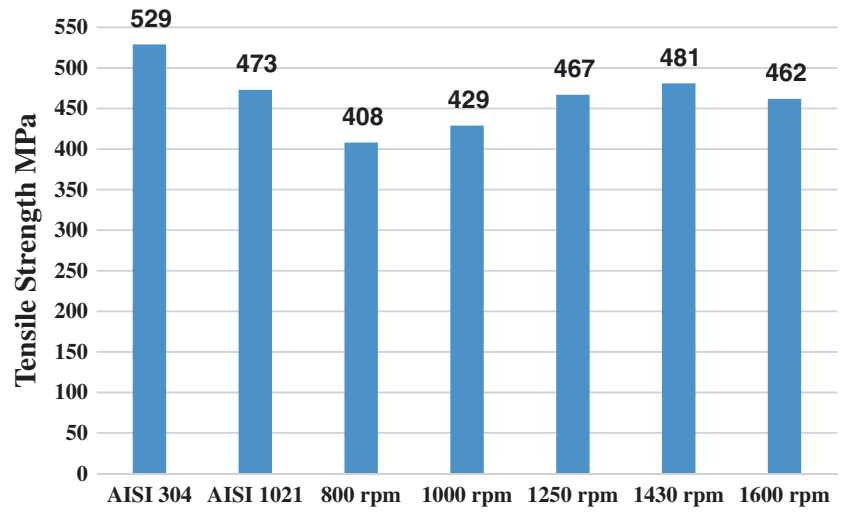

Figure 8. Depicts the comparative tensile strength (MPa) of the un-welded parent materials and the maximum strength of the friction welded specimens available at different rotational speeds.

in comparisons with the friction welded specimen which showed maximum tensile strength. Figure 7 depicts almost similar trends. The maximum tensile strength and the maximum strain was obtained at AISI 304 un-welded parent metal while the minimum values were noticed towards the AISI 1021 parent metal side, even less than the friction welded specimen produced at $1430 \mathrm{rpm}$ and at $120 \mathrm{MPa}$ axial pressures. This friction welded specimen also showed good resistance to the tensile load and failed away from the joint. The strain values were also found to be comparable with that of AISI 304 un-welded parent metal. Figure 8 represents the comparative tensile strength (MPa) of the unwelded parent materials and the maximum strength, achieved at various axial pressures of the friction welded specimens at different rotational speeds. It shows that the maximum strength of the friction welded specimens among all the combinations was found to be at $1430 \mathrm{rpm}$ and was $481 \mathrm{MPa}$.

\subsection{Fractography analysis}

Friction welding experiments were accomplished successfully using determined parameters. During tensile testing brittle break off (figure 9) and ductile break off (figure 10) occurred in the 


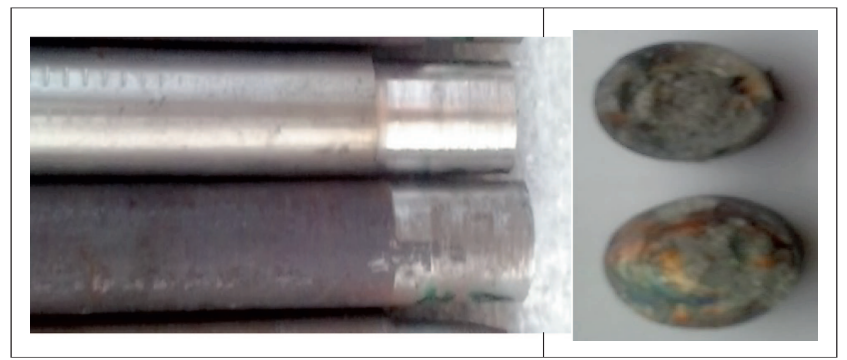

Figure 9. The macrograph of the tensile tested brittle fracture surface of tensile tested specimen.

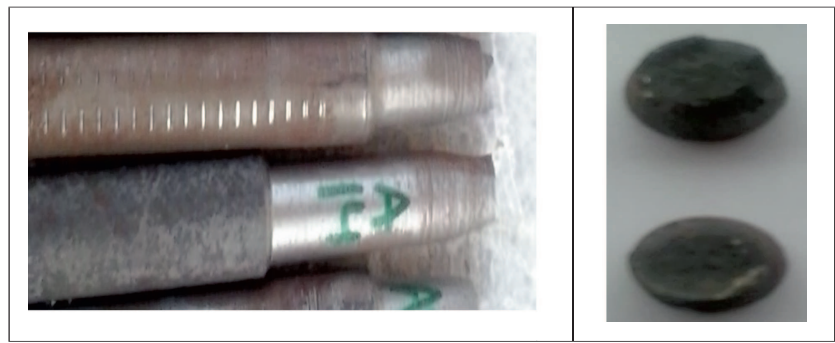

Figure 10. The macrograph of the tensile tested ductile fracture surface of tensile tested specimen.

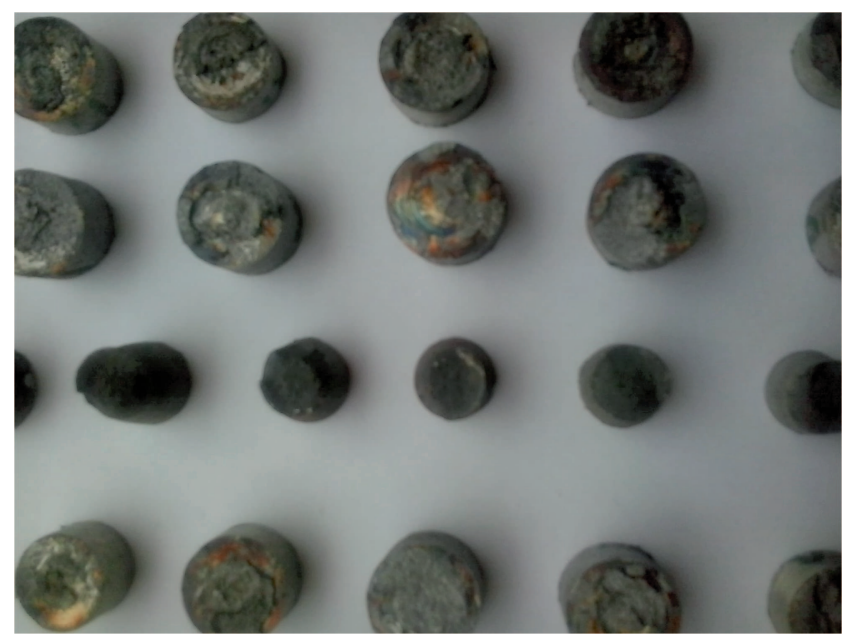

Figure 11. Friction welded specimens cut at the fractured locations for SEM analysis.

specimens. For validating the fracture behavior of tensile tested specimens, fractography analysis was carried out, for this the specimens were cut from the fractured locations keeping the height of the specimen $15 \mathrm{~mm}$ for the ease in the adjustment in specimen holder for SEM analysis as shown in figure 11 . The SEM images of every sample were captured at $1500 \times$ magnifications and are shown in figures (12-16) respectively. Figure 12(a) shows the brittle failure, no voids are visible on the surface and dimples are also absent indicating pure brittle failure (Murr 1986). Figure 12(b) also indicating the brittle failure behavior even though very small amount of dimples appears to be present. Figure 12(c) shows the river-like pattern, the river lines or the stress 


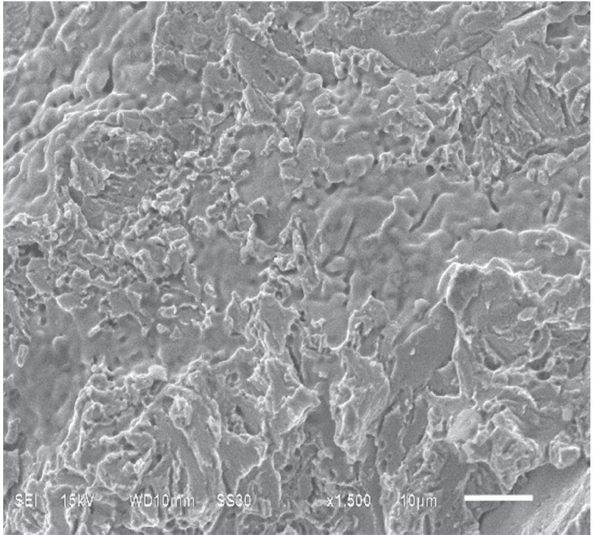

(a)

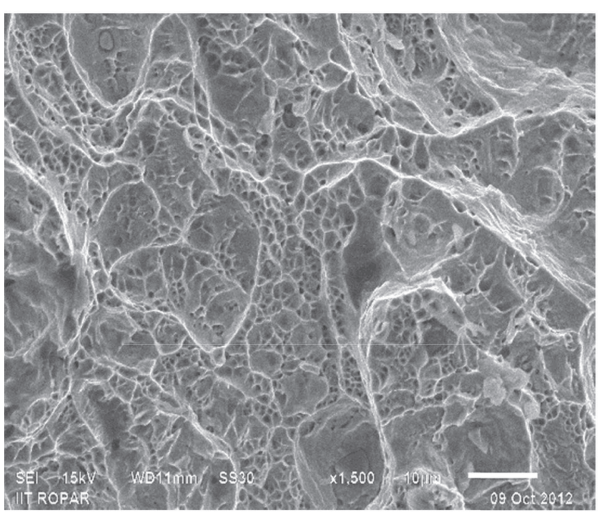

(c)

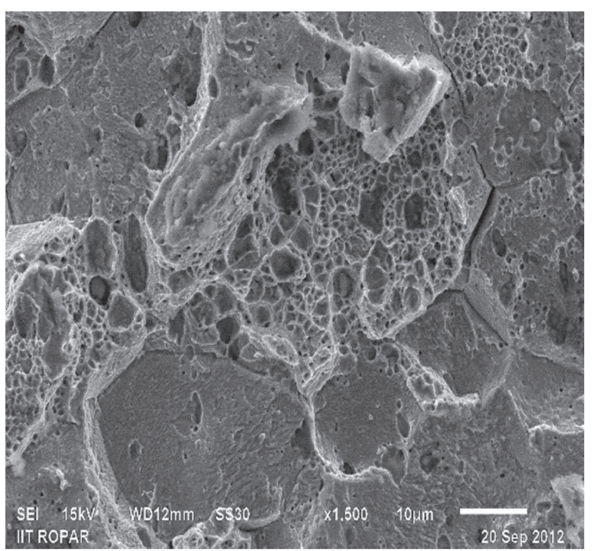

(b)

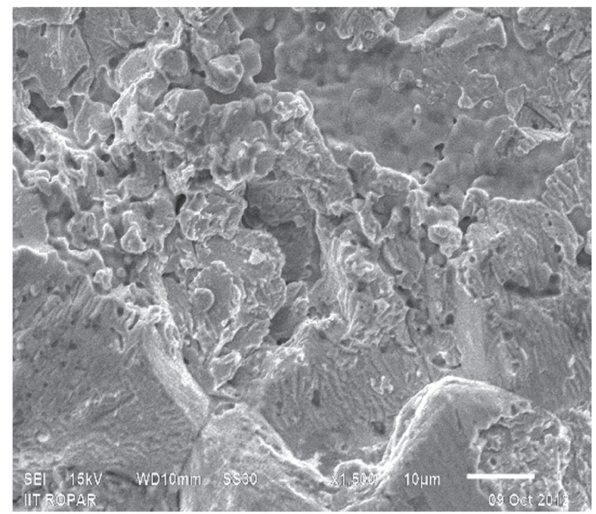

(d)

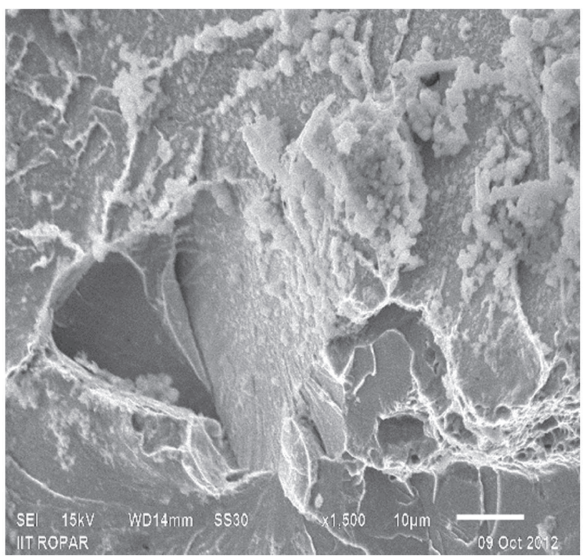

(e)

Figure 12. SEM fractographs of the friction welded AISI 304 and AISI 1021 steel samples failed under tensile testing. The samples were prepared at $800 \mathrm{rpm}$ and at several axial pressures. SEM at (a) $75 \mathrm{MPa}$, (b) $90 \mathrm{MPa}$, (c) $105 \mathrm{MPa}$, (d) $120 \mathrm{MPa}$, (e) $135 \mathrm{MPa}$. 


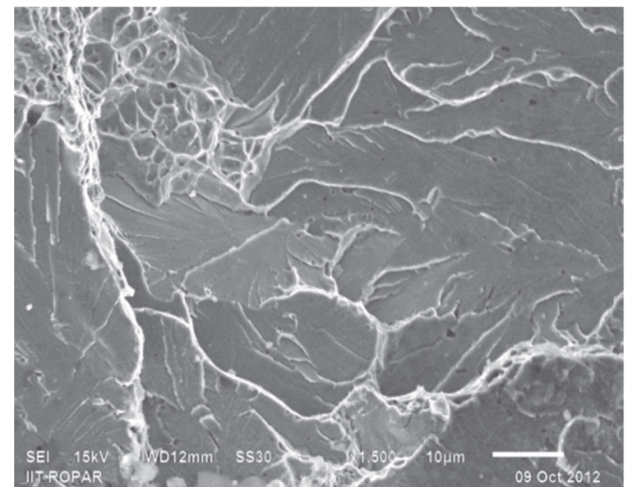

(a)

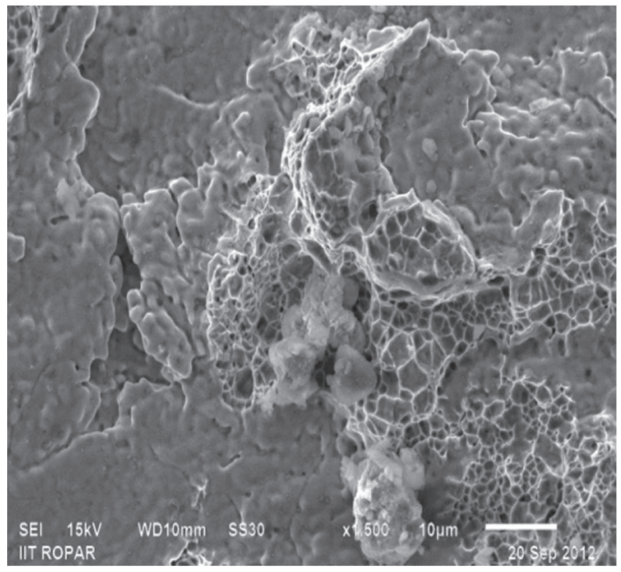

(c)

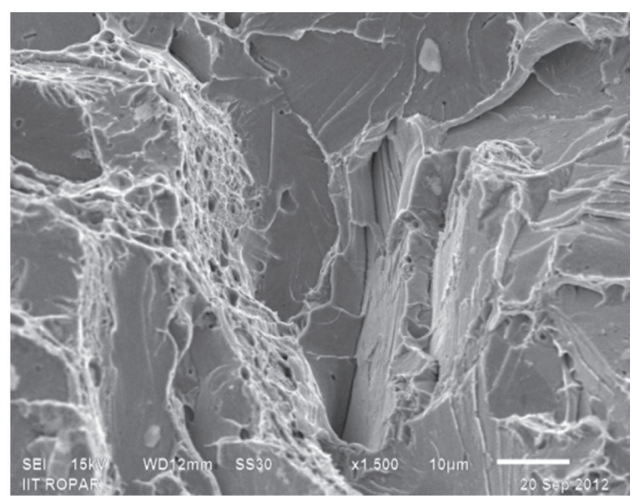

(b)

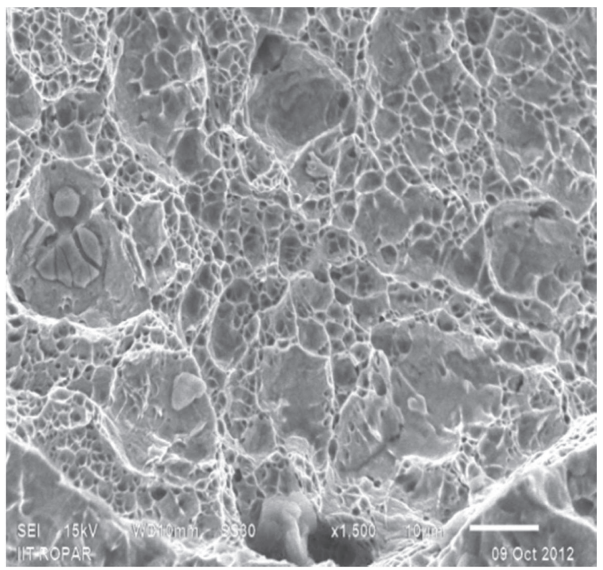

(d)

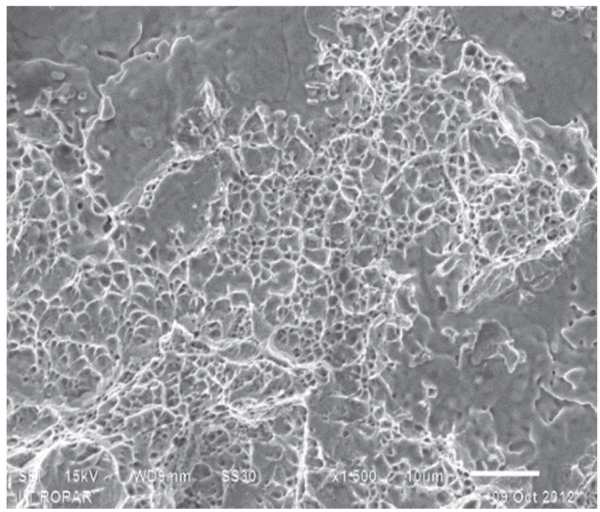

(e)

Figure 13. SEM fractographs of the friction welded AISI 304 and AISI 1021 steel samples failed under tensile testing. The samples were prepared at $1000 \mathrm{rpm}$ and at several axial pressures. SEM at (a) $75 \mathrm{MPa}$, (b) $90 \mathrm{MPa}$, (c) $105 \mathrm{MPa}$, (d) $120 \mathrm{MPa}$, (e) $135 \mathrm{MPa}$. 


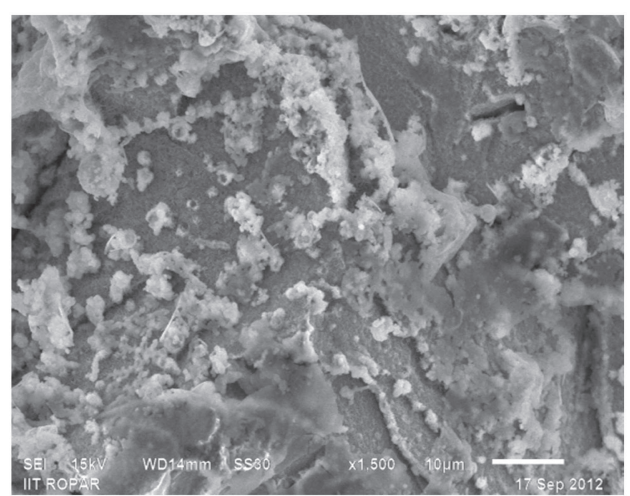

(a)

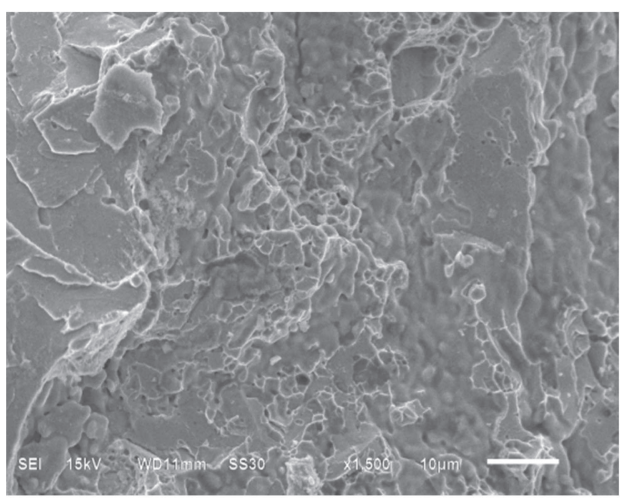

(c)

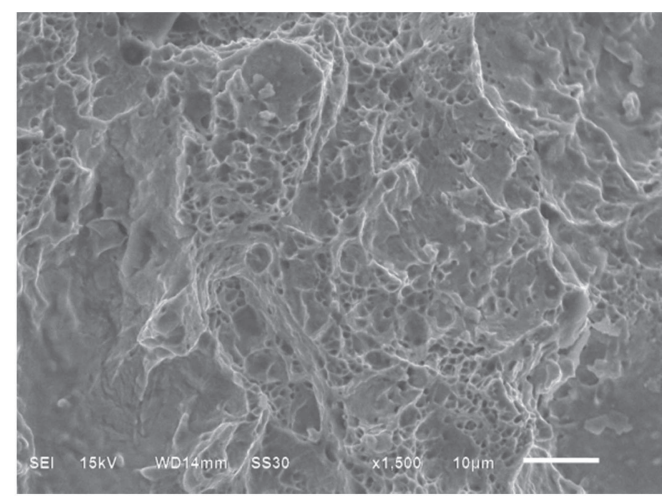

(b)

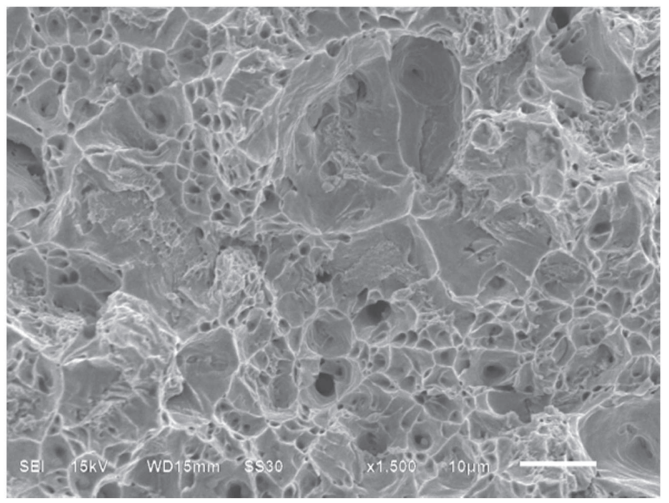

(d)

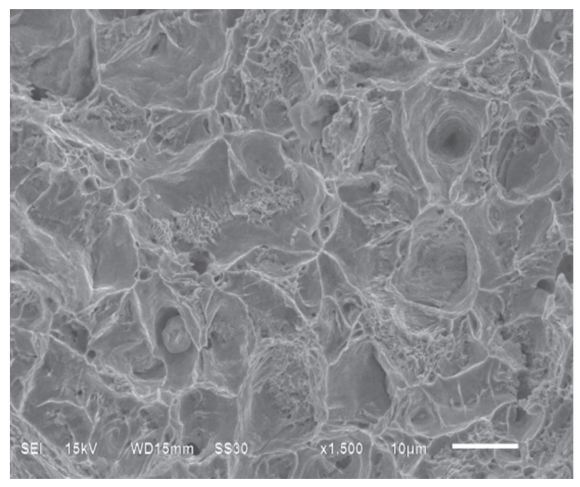

(e)

Figure 14. SEM fractographs of the friction welded AISI 304 and AISI 1021 steel samples failed under tensile testing. The samples were prepared at $1250 \mathrm{rpm}$ and at several axial pressures. SEM at (a) $75 \mathrm{MPa}$, (b) $90 \mathrm{MPa}$, (c) $105 \mathrm{MPa}$, (d) $120 \mathrm{MPa}$, (e) $135 \mathrm{MPa}$. 


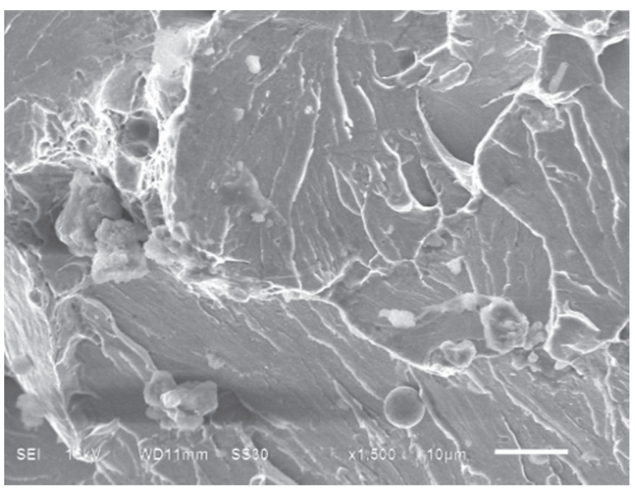

(a)

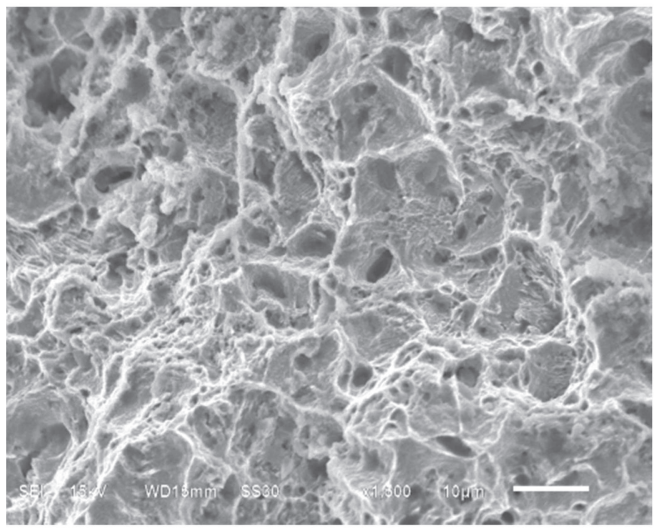

(c)

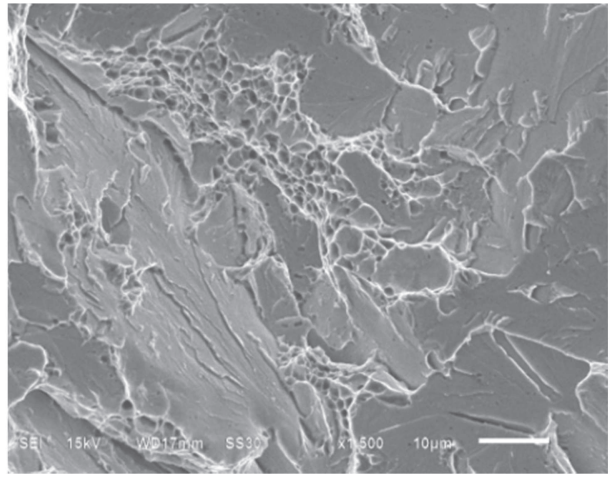

(b)

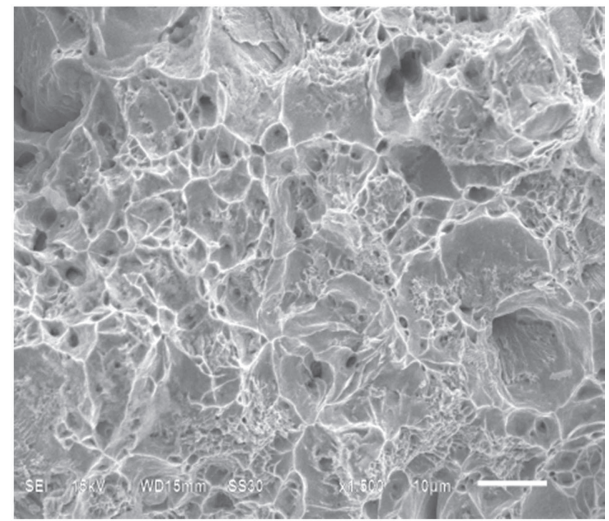

(d)

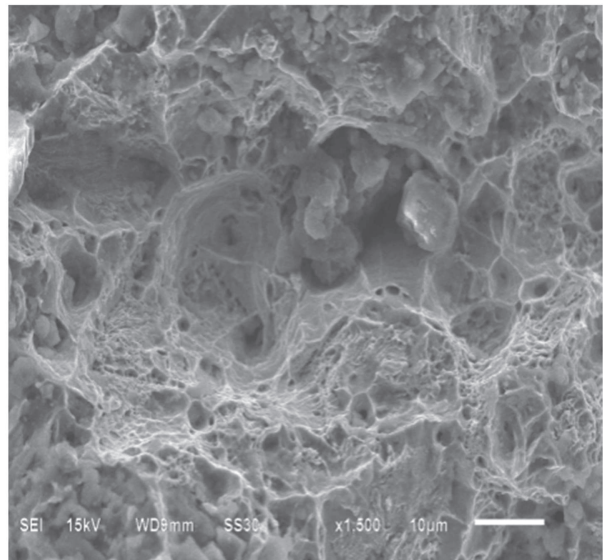

(e)

Figure 15. SEM fractographs of the friction welded AISI 304 and AISI 1021 steel samples failed under tensile testing. The samples were prepared at $1430 \mathrm{rpm}$ and at several axial pressures. SEM at (a) $75 \mathrm{MPa}$, (b) $90 \mathrm{MPa}$, (c) $105 \mathrm{MPa}$, (d) $120 \mathrm{MPa}$, (e) $135 \mathrm{MPa}$. 


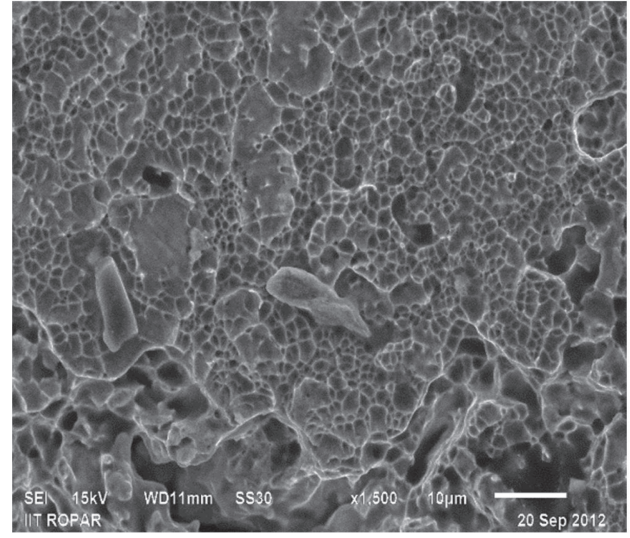

(a)

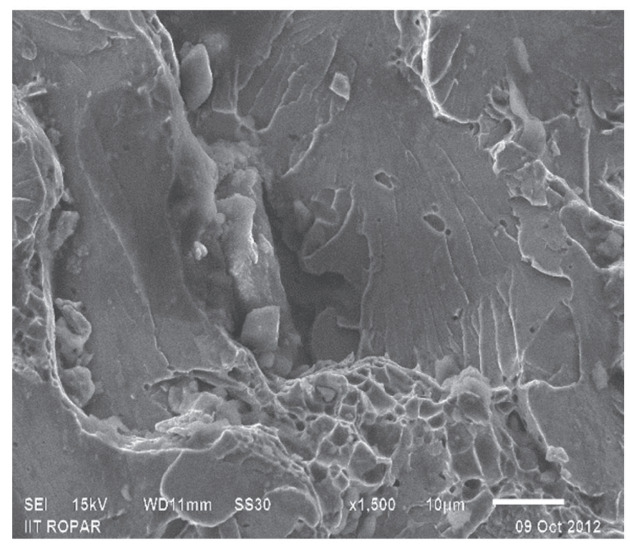

(c)

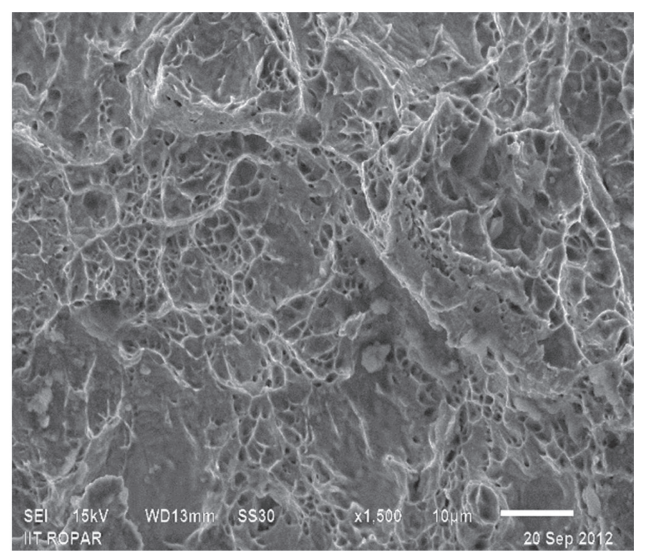

(b)

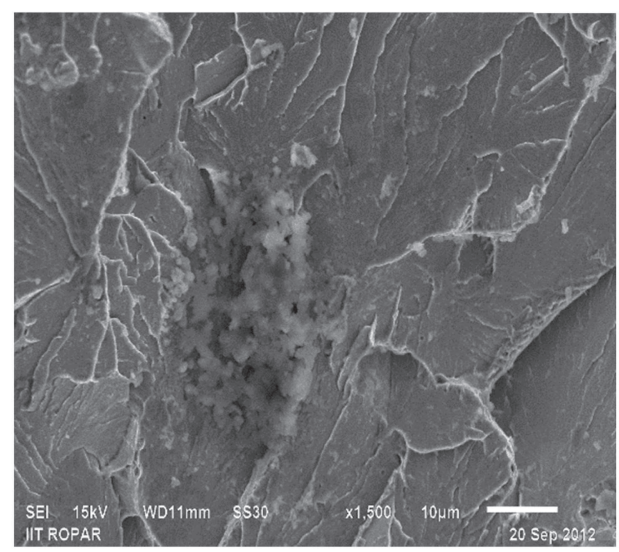

(d)

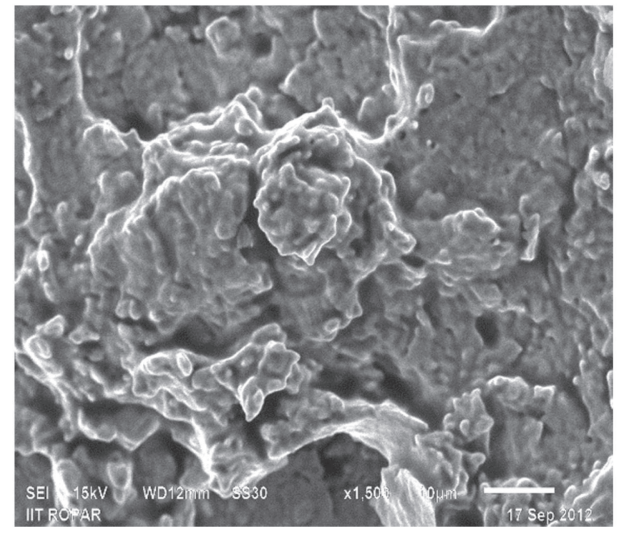

(e)

Figure 16. SEM fractographs of the friction welded AISI 304 and AISI 1021 steel samples failed under tensile testing. The samples were prepared at $1600 \mathrm{rpm}$ and at several axial pressures. SEM at (a) $75 \mathrm{MPa}$, (b) $90 \mathrm{MPa}$, (c) $105 \mathrm{MPa}$, (d) $120 \mathrm{MPa}$, (e) $135 \mathrm{MPa}$. 
lines are steps between cleavage or parallel planes, which are always converged in the direction of local crack propagation leading to the brittle failure of the specimen (ASM Handbook 1987). Figures 12(d), (e), 13(a) and (b) show brittle cleavage fracture features depicting the brittle failure. Figure 13(c) follows the similar pattern as figure 12(b) shows, figure 13(d) and (e) shows small amount of voids and try to pull apart a series of microscopic cups (ASM Handbook 1987). In figure 14(a), the fractograph indicates the pure brittle failure. This may be due to the formation of martensite at the interface of the joints (Ozdemir \& Orhan 2005). Figure 14(b) indicates the sign of river-like pattern, which depicts the brittleness of the joint. Figure 14(c) reveals cleavage pattern as well as dimples at various locations; this indicates that the fracture may have occurred by the mixed phenomenon i.e. quasi cleavage fracture mechanism (Handa \& Chawla 2014a). Figure 14(d) and (e) represents dimpled pattern showing ductile fracture. Figure 14(d) and (e) also depicts that the dimples are deep as compared to figure 14(c) indicating more ductility. In figure 14(d) and (e) the failure was located towards AISI 1021 side therefore ductile fracture similar to that of pure Fe was observed (Meshram et al 2008). Figure 15(a) and (b) indicates brittle failure showing the river like and cleavage pattern respectively (ASM Handbook 1987). Figure 15(c), (d) and (e) depicts dimpled pattern showing ductile failure, figure 15(d) and (e) depicts that the dimples are deep as compared to figure 15(c) indicating more ductility. Figure 16(a) depicts very small size voids and figure 16(b) shows river-like patterns depicting the

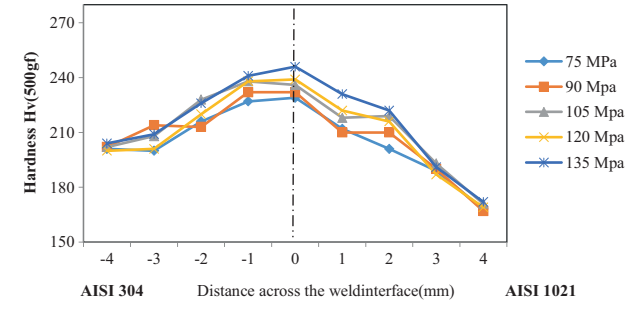

(a)

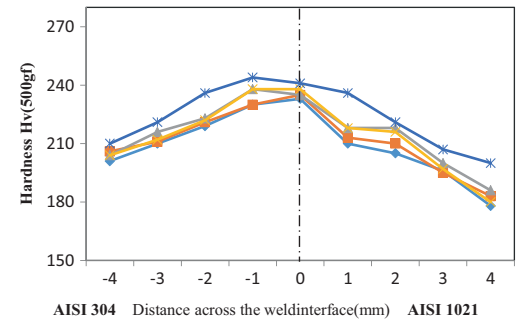

(b)

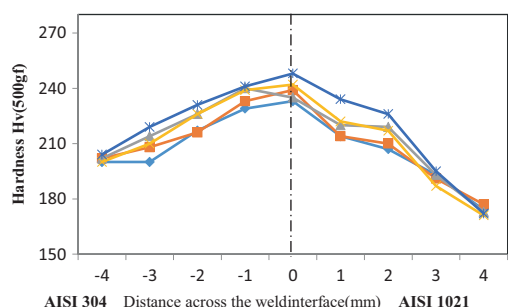

(c)

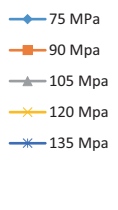

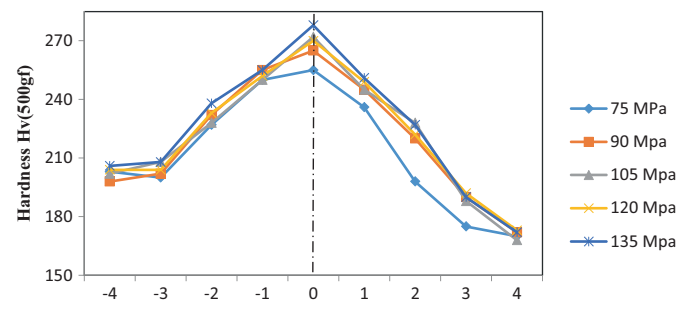

(d) AISI 304 Distance across the weldinterface(mm) AISI 1021

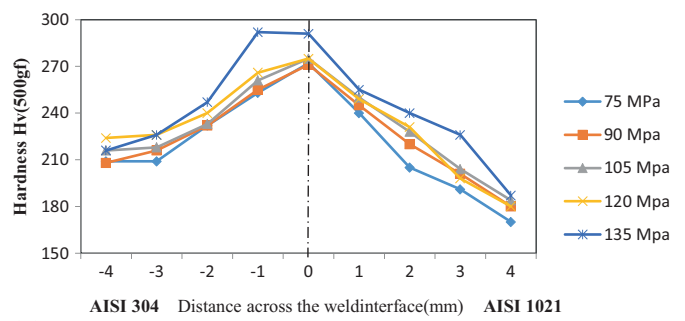

(e)

Figure 17. Shows the variation in hardness under different rpm's and axial pressures. Hardness at (a) $800 \mathrm{rpm}$, (b) $1000 \mathrm{rpm}$, (c) $1250 \mathrm{rpm}$, (d) $1430 \mathrm{rpm}$, (e) $1600 \mathrm{rpm}$. 
brittle failure. Figure 16(c) and (d) shows brittle cleavage fracture. Figure 16(e) also shows the brittle failure, in tensile test this specimen takes minimum time to failure without showing any deformation.

\subsection{Microhardness analysis}

The microhardness variations were obtained on Vickers Hardness Testing Machine, the hardness variations across the weld interface and along the weld interface were obtained by applying a constant load of $500 \mathrm{gf}$ for a dwell period of $10 \mathrm{~s}$ (Handa \& Chawla 2014b). Figure 17(a)-(e) indicates the hardness variations at various rotational speeds and axial pressures. The hardness was measured at the weld interface and on the either side of the parent materials. AISI 1021 indicates less hardness than the AISI 304. This decrease in hardness may be attributed to recrystallization process taking place at the heat affected zone towards the low alloy steel (Ananthapadmanadan et al 2009). It has also been observed that the maximum hardness was obtained at the weld interface for all the joints (Ozdemir \& Orhan 2005). The peak hardness of friction welded joints increases with the increase in burn-off length (Arivazhagan et al 2011). It was observed that with the increase in burn-off length a soft region appears on the austenitic stainless steel adjacent to the weld interface. The formation of soft region can be attributed to decarburization. This may be occurred by the presence of heat as the thermal conductivity of the material is relatively low (Satyanarayana et al 2005). In addition to that the higher values of hardness at the weldinterface were probably due to the oxidation process which takes place during friction welding (Ates et al 2007). The higher hardness values were found to be at austenitic stainless steel side for all the samples. For every sample with the increase in either the axial pressure or the rotational speed, the value of hardness increases. The maximum hardness was found at $1600 \mathrm{rpm}$ and at $135 \mathrm{MPa}$ axial pressures where it crosses the $290 \mathrm{Hv}$ value, this might be the reason that the specimen fails at this parameter without giving any deformation.

\section{Conclusions}

The friction welded joints of AISI 304 austenitic stainless steel with AISI 1021 ferritic steel was achieved successfully using several rotational speeds $(800 \mathrm{rpm}-1600 \mathrm{rpm})$ using different axial pressures (75 $\mathrm{MPa}-135 \mathrm{MPa})$. It has been concluded from the above investigation that the axial pressure and rotational speeds are the major parameters which can influence the strength of the joint. With the increase in the axial pressure the joint strength increases, the joint strength also increases with the increases in the rotational speed as well. The maximum joint strength was found to be available at $1430 \mathrm{rpm}$ and at $120 \mathrm{MPa}$ axial pressure and was $1.8 \%$ higher than AISI 1021 parent metal, while the lowest tensile strength was found to be $80 \%$ of the AISI 1021 parent metal and was observed at $1000 \mathrm{rpm}$ and $75 \mathrm{MPa}$ axial pressure. In this study it has been found that the strength firstly increases, reaches the maximum value and then starts declining. At 1430 rpm and at $120 \mathrm{MPa}$ axial pressures, maximum strain value of 0.44 was also observed and the specimen fails from the parent material and not from the weld interface. The SEM results also support the tensile results showing the deep dimples at the aforesaid parameters indicating the ductile failure, and the hardness values were also found to be satisfactory at these parameters.

\section{Acknowledgement}

The authors wish to express their gratitude to Dr. Harpreet Singh, Associate Professor, IIT Ropar, India for providing the research facility to test the friction welded specimens. They 
also acknowledge Professor Deepinder Singh, Head, Department of Mechanical Engineering, RIMT-IET, Mandi Gobindgarh, India for his valuable guidance for revising the paper.

\section{References}

Ananthapadmanadan D, Rao V S, Abraham N and Rao K P 2009 A study of mechanical properties of friction welded mild steel to stainless steel joints. Mater. Des. 30: 2642-2646

Arivazhagan N, Singh S, Prakash S and Reddy G M 2011 Investigation of AISI 304 austenitic stainless steel to AISI 4140 low alloy steel dissimilar joints by gas tungsten arc, electron beam and friction welding. Mater. Des. 32: 3036-3050

ASM Handbook 1987 Fractography 12: 43-58

ASM Handbook 1993 Fundamentals of friction welding 6A: 105-155

Ates H, Turker M and Kurt A 2007 Effect of friction pressure on the properties of friction welded MA956 iron-based superalloy. Mater. Des. 28: 948-953

Celik S and Ersozlu I 2009 Investigation of mechanical properties and microstructure of friction welded joints between AISI 4140 and AISI 1050 steels. Mater. Des. 30: 970-976

Chander G S, Reddy G M and Tagore G R N 2012 Influence of process parameters on impact toughness and hardness of dissimilar AISI 4140 and AISI 304 continuous drive friction welds. Int. J. Adv. Manuf. Technol. 64: 1445-1457

Handa A and Chawla V 2013a Experimental study of mechanical properties of friction welded AISI 1021 steels. Sadhana - Academy Proceedings in Engineering Sciences 38: 1407-1419

Handa A and Chawla V 2013b Mechanical characterization of friction welded dissimilar steels at 1000 rpm. Mater. Eng. - Materiálovéinžinierstvo 20: 102-111

Handa A and Chawla V 2014a Investigation of mechanical properties of friction-welded AISI 304 with AISI 1021 dissimilar steels. Int. J. Adv. Manuf. Technol. 75: 1493-1500

Handa A and Chawla V 2014b Experimental evaluation of mechanical properties of friction welded AISI steels. Cogent Eng. DOI: 10.1080/23311916.2014.936996

Kurt A, Uygur I and Paylasan U 2011 Effect of friction welding parameters on mechanical and microstructural properties of dissimilar AISI 1010 - ASTM B22 joints. Welding Res. 90: 102-106

Meshram S D, Mohandas T and Reddy G M 2008 Friction welding of dissimilar pure metals. J. Mater. Process. Technol. 184: 330-337

Murr L E 1986 Material and component failure, failure analysis, and litigation 20: 74

Ozdemir N and Orhan N 2005 Microstructure and mechanical properties of friction welded joints of a fine-grained hypereutectoid steel with 4\% Al. J. Mater. Process. Technol. 166: 63-70

Reddy G M and Rao K S 2009 Microstructure and mechanical properties of similar and dissimilar stainless steel electron beam and friction welds. Int. J. Adv. Manuf. Technol. 45: 875-888

Sahin M 2009 Characterization of properties in plastically deformed austenitic-stainless steels joined by friction welding. Mater. Des. 30: 135-144

Sahin M, Akata H E and Gulmez T 2007 Characterization of mechanical properties in AISI 1040 parts welded by friction welding. Mater. Charact. 58: 1033-1038

Sathiya P, Aravindan S and Haq A N 2005 Mechanical and metallurgical properties of friction welded AISI 304 austenitic stainless steel. Int. J. Adv. Manuf. Technol. 26: 505-511

Sathiya P, Aravindan S and Haq N A 2007 Some experimental investigations on friction welded stainless steel joints. Mater. Des. 153: 1099-1109

Satyanarayana V V, Reddy G M and Mohandas T 2005 Dissimilar metal friction welding of austeniticferritic stainless steel. J. Mater. Process. Technol. 160: 128-137

Uzkut M, Sadik B U and Akdag M 2011 Determination of optimum welding parameters in connecting high alloyed X53CrMnNiN219 and X45CrSi93. Bull. Mater. Sci. 34: 815-823

Vinoth M K and Balasubramanian V 2014 Microstructure and tensile properties of friction welded SUS 304HCu austenitic stainless steel tubes. Int. J. Pressure Vessels Piping 113: 25-31 